\title{
Konsep Penataan Ruang Kawasan Rawan Bencana (KRB) Tsunami di Kabupaten Karangasem, Pulau Bali
}

\author{
Spatial Planning Concept of Tsunami Disaster Prone Area \\ in Karangasem Regency, Bali Island
}

\author{
Rizki Kirana Yuniartanti ${ }^{*}$ \\ ${ }^{1}$ Universitas Esa Unggul, Jalan Arjuna Utara Nomor 9, Duri Kepa, Kecamatan Kebon Jeruk, \\ Kota Jakarta Barat, Daerah Khusus Ibukota Jakarta 11510, Indonesia; \\ *Penulis korespondensi.e-mail: rizki.kirana@esaunggul.ac.id \\ (Diterima: 24 Mei 2020; 22 September 2020)
}

\begin{abstract}
The island of Bali and its surrounding are part of Indonesia's seism tectonic system. The condition has been faced including by Karangasem Regency. Karangasem Regency is prone by seismic and tsunami disaster. The high level of disaster proneness in Karangasem Regency requires disaster preparedness in pre-disaster phase. Rehabilitation and reconstruction responses are not been effective since these steps require expensive funding and investment. Preparedness efforts in pre-disaster phase are carried out through quality enhancement of spatial plans based on Disaster Risk Reduction (DRR). This research is aimed to provide recommendation for spatial plan, including spatial pattern (land use) plan and development of mitigation infrastructure. This research uses qualitative and quantitative research methods. Analysis tools are Geographic Information Systems (GIS), good practices, and literatures, as well as policies from various sources. The output of this study resulted in a spatial assessment according to the level of tsunami disaster prone level.
\end{abstract}

Keywords: disaster mitigation, spatial plan, tsunami

\begin{abstract}
ABSTRAK
Pulau Bali dan kawasan sekitarnya termasuk bagian dari seismotektonik Indonesia. Kondisi tersebut juga terjadi di Kabupaten Karangasem. Kabupaten Karangasem memiliki tingkat kerawanan bencana gempa bumi maupun tsunami. Tingkat kerawanan bencana yang tinggi di Kabupaten Karangasem membutuhkan kesiapsiagaan di tahapan pra bencana. Respon rehabilitasi dan rekonstruksi tidaklah efektif karena memerlukan pembiayaan dan investasi yang besar. Upaya kesiapsiagaan pada tahapan pra bencana dilakukan melalui peningkatan kualitas tata ruang berdasarkan Pengurangan Risiko Bencana (PRB). Penelitian ini bertujuan memberikan rekomendasi muatan rencana pola ruang dan pengembangan infrastruktur mitigasi. Dalam penelitian ini menggunakan kolaborasi metode penelitian kualitatif dan kuantitatif dengan alat analisis Sistem Informasi Geografis (SIG), praktek baik, dan literatur, maupun kebijakan dari berbagai sumber. Output dari penelitian ini menghasilkan arahan rekomendasi tata ruang sesuai dengan tingkat kerawanan bencana tsunami.
\end{abstract}

Kata kunci: mitigasi bencana, tata ruang, tsunami 


\section{PENDAHULUAN}

Indonesia merupakan daerah rawan bencana karena letaknya berada di ring of fire (Soemabrata et al., 2018), sehingga memiliki kerentanan tinggi dari bahaya bencana geologi yang meliputi gempa bumi, letusan gunung api, gerakan tanah/longsor, dan tsunami. Berdasarkan data dari BMKG (2018), Pulau Bali dan kawasan sekitarnya termasuk bagian dari seismotektonik Indonesia. Daerah ini dilalui jalur Pegunungan Mediteranian dan zona subduksi akibat pertemuan Lempeng Indo-Australia dan Lempeng Eurasia. Dengan kondisi tersebut mengakibatkan Pulau Bali memiliki tingkat kerawanan bencana cukup tinggi. Berdasarkan data BPBD Provinsi Bali, kerawanan bencana di Provinsi Bali terdiri atas letusan Gunungapi Agung, tanah longsor di wilayah Bali bagian Tengah, banjir di bagian utara Kabupaten Buleleng, bagian selatan Kabupaten Jembrana, Badung dan Kota Denpasar, dan gempabumi di sebagian besar wilayah Pulau Bali. Kerawanan bencana juga berkaitan dengan aktivitas subduksi lempeng di bawah Paparan Sunda dan juga kelanjutan garis Busur Sunda ke arah timur yang bertemu dengan Busur Banda. Sebagai akibat dari pergerakan lempeng-lempeng ini adalah adanya tipe-tipe tektonik yang merupakan ciri dari sistem subduksi.

Undang-Undang Nomor 26 Tahun 2007 tentang Penataan Ruang (UUPR) mengamanatkan penataan ruang yang berbasis mitigasi bencana untuk mewujudkan wilayah yang aman, nyaman, produktif, dan berkelanjutan. Undang-Undang Nomor 24 Tahun 2007 tentang Penyelenggaraan Penanggulangan Bencana (UUPPB) juga diatur bahwa mitigasi sebagai serangkaian upaya untuk mengurangi risiko bencana. Dengan meninjau amanat kedua UU tersebut, menunjukkan bahwa penataan ruang berbasis mitigasi bencana merupakan salah satu upaya atau Pengurangan Risiko Bencana (Disaster Risk Reduction/ DRR). Respon terhadap bencana dalam bentuk mitigasi bencana yang seiring dengan upaya mereka untuk menstabilkan dan meningkatkan standar kehidupan (Wisner et al., 2005).

Dalam penyelenggaraan penanggulangan bancana terdiri atas tahapan pra bencana, saat bencana, dan pasca bencana. Tata ruang termasuk dalam tahapan pra bencana. Sehingga rencana tata ruang lebih efektif sebagai mitigasi bencana/PRB. Tujuan dari penataan ruang yang berbasis mitigasi bencana/PRB adalah mewujudkan ketahanan wilayah dari bencana (Sutanta, 2012). Tata ruang dapat meminimalisir risiko bencana pada tahapan pra bencana yang akan lebih efektif termasuk penghematan sari segi pembiayaan dibandingkan tahapan rehabilitasi dan rekonstruksi.

Pertimbangan karakteristik bencana di Kabupaten Karangasem dan mengacu kebijakan penataan ruang serta penyelenggaraan penanggulangan bencana, maka diperlukan penataan ruang KRB berbasis mitigasi bencana/PRB Gunungapi Agung di Kabupaten Karangasem, Provinsi Bali. Penelitian ini bertujuan memberikan rekomendasi muatan rencana pola ruang dan pengembangan infrastruktur mitigasi sebagai masukan penataan ruang berbasis mitigasi bencana/PRB bagi Pemerintah Kabupaten Karangasem. Output dari penelitian ini adalah arahan rekomendasi pemanfaatan ruang di KRB tsunami Kabupaten Karangasem.

\section{METODOLOGI}

Metode yang digunakan dalam penelitian ini adalah kolaborasi kualitatif dan kuantitatif. Metode kualitatif untuk mendapatkan informasi, kebijakan, rencana, dan program mitigasi bencana dari Pemerintah Daerah Provinsi Bali, Pemerintah Kabupaten Karangasem, dan masyarakat. Sedangkan metode kuantitatif digunakan untuk menganalisis risiko bencana. Alat analisis yang digunakan adalah Sistem Informasi Geografis (SIG) dan telaah praktik baik dan literatur maupun kebijakan dari berbagai sumber. Analisis SIG digunakan untuk menentukan 
tingkat risiko bencana dengan sumber data kerawanan bencana Gerakan Tanah (2016), Letusan Gunungapi (2015), Alur Bahan Rombakan (2016), dan Tsunami (2013) yang berasal dari Badan Geologi, Kementerian Energi dan Sumber Daya Mineral. Arahan rekomendasi tata ruang berdasarkan kebijakan Peraturan Menteri Agraria dan Tata Ruang/Kepala Badan Pertanahan Nasional No 1 Tahun 2018 tentang Pedoman Penyusunan Rencana Tata Ruang Wilayah Provinsi, Kabupaten, dan Kota dan juga hasil telaah literatur dan praktik pemanfaatan ruang dan mitigasi bencana pada kawasan pesisir di Jepang dan Yunani serta mitigasi bencana di Gunung Rainier di Washington.

Metode perhitungan risiko bencana merupakan modifikasi dari metode yang terdapat dalam Perka BNPB No 2 Tahun 2012. Pada formula risiko [Gambar 1], tingkat ancaman kawasan direpresentasikan secara spasial sebagai tingkat bahaya yang diambil dari klasifikasi Peta Kawasan Rawan Bencana (KRB) pada setiap jenis bencana.

Tingkat kerentanan diwakili oleh keterpaparan fisik terhadap kondisi bahaya dengan menggunakan komposit keterpaparan dari parameter kepadatan penduduk dan kepadatan bangunan dengan asumsi bahwa apabila tinggal pada wilayah yang terdapat bahaya bencana, maka penduduk tersebut menjadi rentan terhadap bencana tersebut serta asumsi jumlah penduduk berasosiasi dengan keberadaan bangunan/properti (Cross, 2001).

\section{HASIL DAN PEMBAHASAN}

\section{Kerawanan Bencana Tsunami Kabupaten Karangasem}

Seluruh kawasan pesisir dan sempadan pantai di Kabupaten Karangasem termasuk pada KRB Tsunami. Kecamatan Abang, Kecamatan Karangasem, Kecamatan Kubu, dan Kecamatan Manggis termasuk dalam KRB tsunami. Kecamatan Manggis dan Kecamatan Karangsem merupakan area dengan luasan terbesar untuk wilayah yang berada di KRB tsunami tinggi, dengan luas $181.40 \mathrm{Ha}$ dan $117.58 \mathrm{Ha}$.

Luas wilayah total yang berada pada KRB tsunami adalah 1,194.38 atau $1.42 \%$ dari luas total Kabupaten Karangasem. Luas wilayah yang termasuk pada KRB tsunami tinggi adalah $32.52 \mathrm{Ha}$ atau $0.40 \%$ dari luas wilayah Kabupaten Karangasem. Wilayah yang termasuk dalam KRB menengah luasnya adalah $34.25 \mathrm{Ha}$ atau $0.41 \%$ dari luas wilayah Kabupaten Karangasem. Sedangkan wilayah yang termasuk pada KRB tsunami rendah luasnya adalah $520.61 \mathrm{Ha}$ atau 0.62 dari luas keseluruhan Kabupaten Karangasem [Gambar 2].

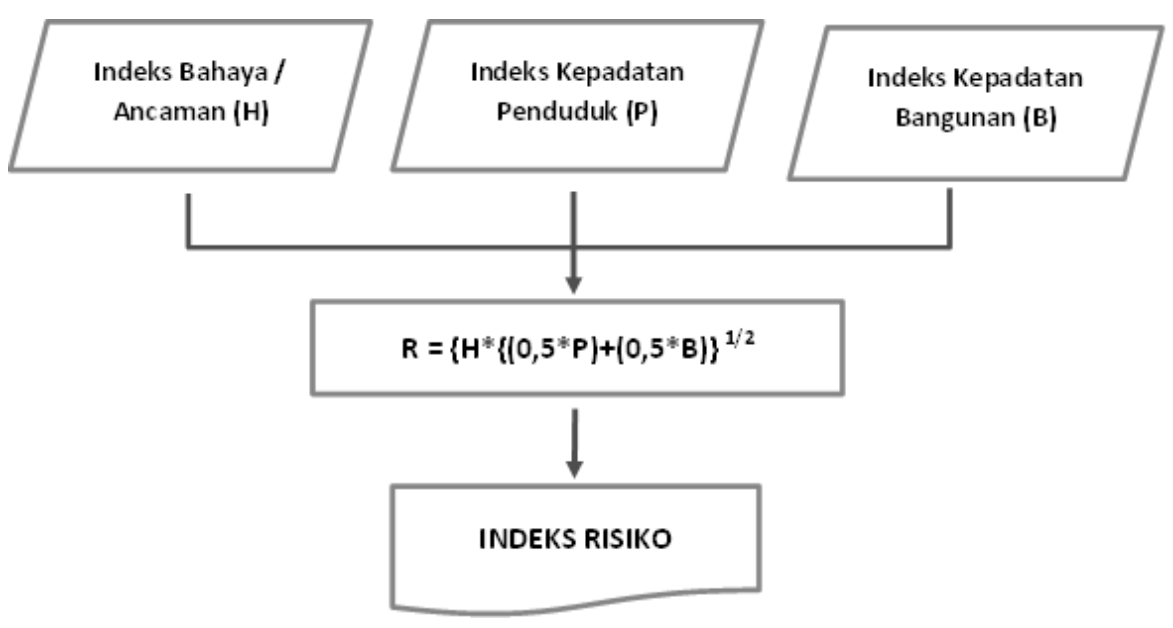

Gambar 1. Diagram alir metode pengkajian risiko bencana

Sumber: Hasil pengolahan data tim penyusunan masterplan Kawasan Rawan Bencana (KRB) Gunung Agung di Kabupaten Karangasem, 2019 


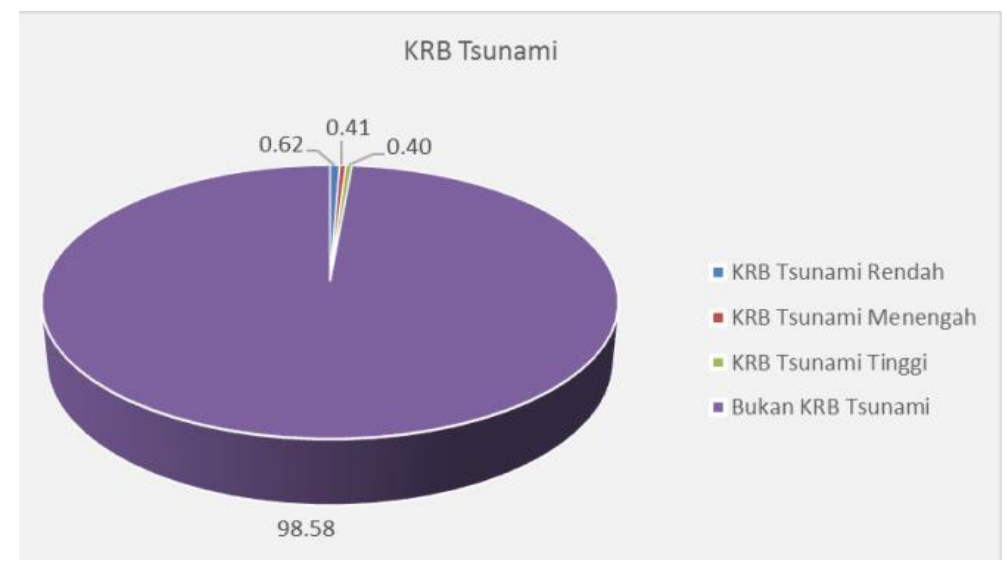

Gambar 2. Diagram persentase luasan KRB tsunami di Kabupaten Karangasem

Delineasi KRB tsunami hanya pada kawasan pesisir. Sehingga dapat disimpulkan bahwa memang KRB tsunami hanya mendominasi pada wilayah pesisir di Kabupaten Karangasem [Gambar 3].

\section{Analisis Risiko Bencana Tsunami}

Klasifikasi risiko bencana terbagi menjadi 3 (tiga), yaitu rendah, sedang, dan tinggi. Kabupaten Karangasem didominasi oleh risiko sedang, seperti Kecamatan Kubu yang berada pada pantai sisi utara Kabupaten
Karangasem, seperti terlihat pada Tabel 1 dan Gambar 4. Pantai sisi selatan Kabupaten Karangasem memiliki risiko bencana tsunami yang tinggi. Apabila dibandingkan pantai yang berada pada sisi utara dengan sisi selatan, maka risiko tsunami pada pantai yang berada di sisi selatan lebih besar karena terdapat potensi tsunami dari gempa di selatan Pulau Bali. Hanya saja perhatian khusus diperlukan pada daerah yang mempunyai risiko tinggi maupun sedang karena merupakan daerah padat penduduk dan pusat perekonomian.

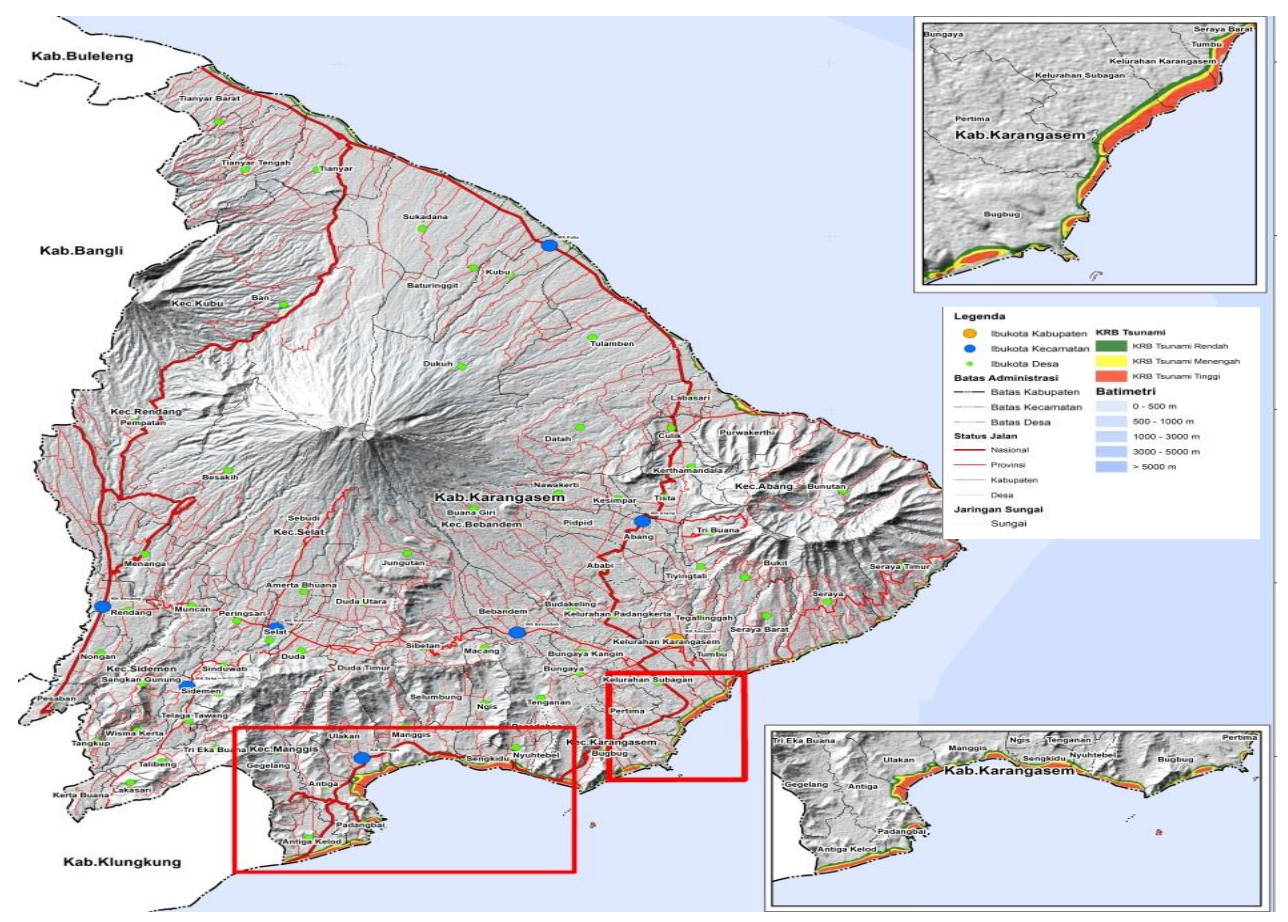

Gambar 3. Peta KRB Tsunami di Kabupaten Karangasem Sumber: Badan Geologi, 2013 
Tabel 1 Tingkat risiko bencana tsunami di Kabupaten Karangasem

\begin{tabular}{lllll}
\hline No. & Kecamatan & \multicolumn{3}{c}{ Tingkat Risiko } \\
& & & \multicolumn{3}{c}{ (Jumlah Desa) } \\
\cline { 3 - 5 } & & Rendah & Sedang & Tinggi \\
\hline 1 & Abang & 3 & 3 & 3 \\
2 & Karangasem & 4 & 3 & 5 \\
3 & Kubu & 8 & 8 & 3 \\
4 & Manggis & 6 & 6 & 6 \\
\hline
\end{tabular}

Sumber: Hasil pengolahan data tim penyusunan masterplan Kawasan Rawan Bencana (KRB) Gunung Agung di Kabupaten Karangasem, 2019

\section{Kebijakan dan Praktik Baik terkait Sistem Prasarana Mitigasi Bencana Tsunami}

Kebijakan dan praktik baik penetapan sempadan pantai minimal 100 meter, upaya pengembangan mitigasi struktural dan nonstruktural, dan penyediaan sistem prasarana mitigasi bencana tsunami yang dapat dijadikan acuan untuk kawasan pesisir di Kabupaten Karangasem. Berikut ini penjelasannya.

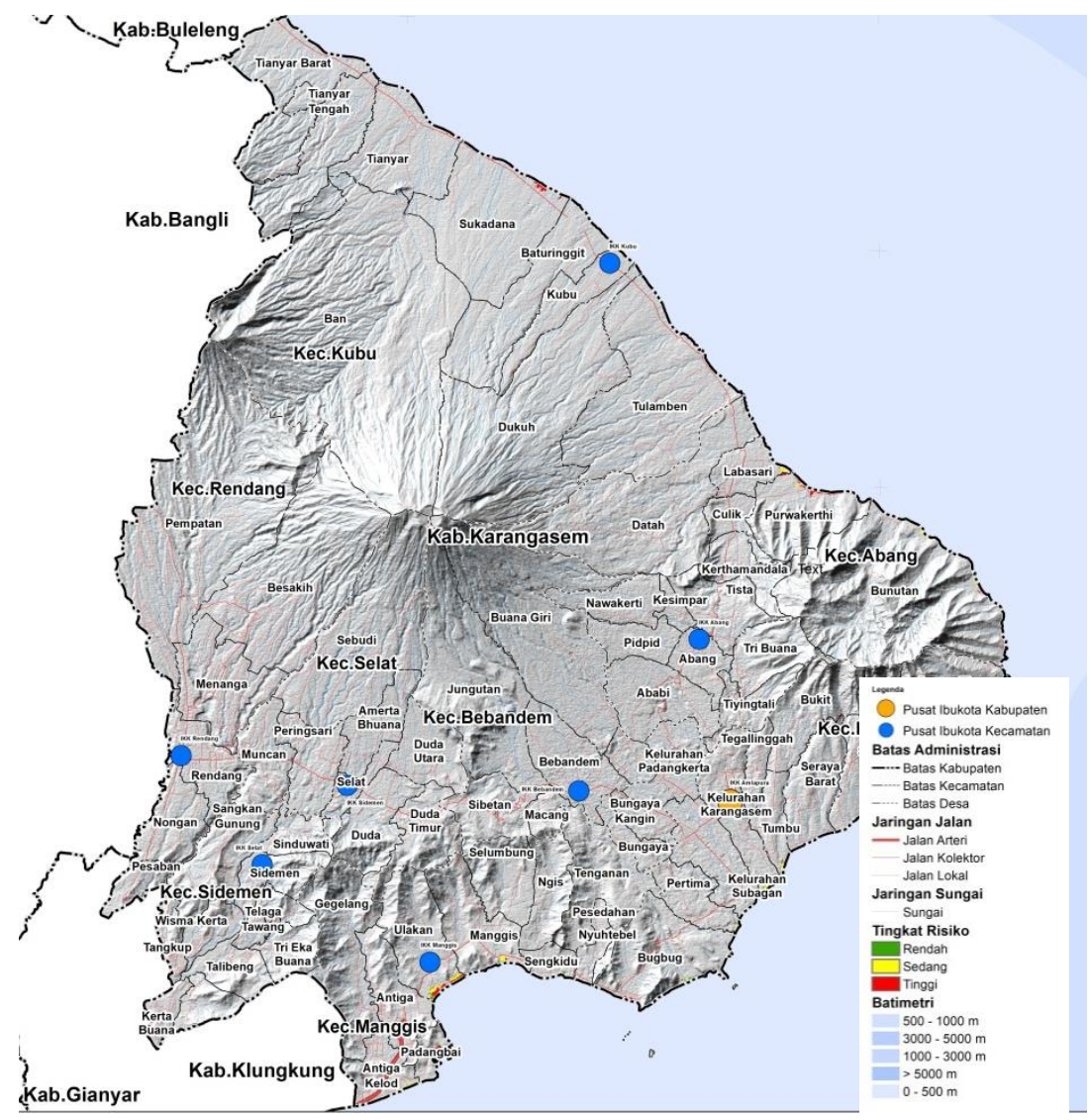

Gambar 4. Peta risiko bencana tsunami di Kabupaten Karangasem

Sumber: Hasil Pengolahan Data Tim Penyusunan Masterplan Kawasan Rawan Bencana (KRB) Gunung Agung di Kabupaten Karangasem, 2019

1. Peraturan Presiden No. 51 Tahun 2016 tentang Batas Sempadan Pantai

Pada peraturan ini memuat perhitungan batas sempadan pantai berdasarkan tingkat risiko bencana. Tingkat risiko bencana tersebut mempertimbangkan komponen ancaman dan kerentanan.

Indeks kerawanan ditentukan berdasarkan variabel kerawanan gempa bumi, tsunami, erosi, atau abrasi, badai, dan banjir dari laut. Sedangkan variabel kerentanan bencana yang terdiri atas karakteristik topografi, biofisik, hidro-oseanografi pesisir, kebutuhan ekonomi dan budaya, dan ketentuan lain. Perhitungan batas sempadan pantai ditentukan berdasarkan batas akhir keberadaan ekosistem pesisir ke arah darat dan juga aktivitas di wilayah pesisir dan pulau-pulau kecil tersebut. Penetapan batas sempadan pantai untuk 
daerah kawasan rawan bencana kepesisiran dapat dilakukan dari hasil perhitungan dengan ketentuan wajib menerapkan pedoman bangunan (building code) yang mempertimbangkan mitigasi bencana.

2. Peraturan Menteri Agraria dan Tata Ruang/Kepala Badan Pertanahan Nasional Nomor 1 Tahun 2018 tentang Pedoman Penyusunan Rencana Tata Ruang Wilayah Provinsi, Kabupaten, dan Kota.

Pengaturan sempadan pantai pada Peraturan Menteri ATR/Kepala BPN No. 1 Tahun 2018 terdapat pada rencana pola ruang yaitu kawasan peruntukan lindung. Dalam muatan RTRW Provinsi, kawasan perlindungan setempat mengamanatkan pengaturan batas sempadan pantai dan arahan kawasan sekitar danau atau waduk sebagai acuan bagi pemerintah kabupaten/kota.

Kawasan perlindungan setempat terdiri atas sempadan sungai, sempadan pantai, kawasan sekitar danau atau waduk, dan kawasan lindung spiritual dan kearifan lokal.

3. Perencanaan Pembangunan Lahan Kawasan Pesisir yang Berkelanjutan (Studi Kasus Negara Yunani).

Praktik baik ini didapat dari penelitian Kotsoni et al., (2017). Dalam penelitiannya, didapat pembelajaran negara Yunani dalam pengaturan pemanfaatan ruang kawasan pesisir terutama sempadan pantai. Sempadan pantai diklasifikasikan sebagai zona yang tidak boleh di kembangkan, yaitu 50 meter dari pantai. Zona ini tidak boleh dimanfaatkan sebagai kawasan terbangun. Zona yang diizinkan sebagai pengembangan kawasan pariwisata/ekonomi (di luar sempadan pantai minimal 50 meter) dan intensitas bangunan sedang hingga rendah.

Zona sempadan pantai minimal 50 meter yang yang diperuntukkan sebagai kawasan penyangga, tidak diperuntukkan sebagai kawasan pariwisata/ekonomi dengan membangun akomodasi pariwisata, tetapi diperbolehkan melakukan aktivitas wisata.
Kawasan pariwisata disertai dengan penyediaan akses jalan menuju pantai minimal 10 meter dan dapat diakses oleh publik. Zona yang diperuntukkan aktivitas wisata harus menyediakan akses jalan baik dalam sempadan pantai maupun di luar sempadan pantai. Kawasan penyangga dapat berupa (RTH), sabuk hijau, dan mitigasi non struktural, seperti sand dunes. Pada area belakang kawasan penyangga dapat didesain sebagai fungsi jalur sepeda dan jalur pejalan kaki dengan ketentuan ketinggian 1 meter dari kawasan penyangga dan konstruksi material kayu, kemudian baru dapat dikembangkan aktivitas pariwisata/ekonomi dengan tetap memberikan ruang untuk RTH. Gambar 5 adalah akses jalan yang mendukung kegiatan pariwisata.

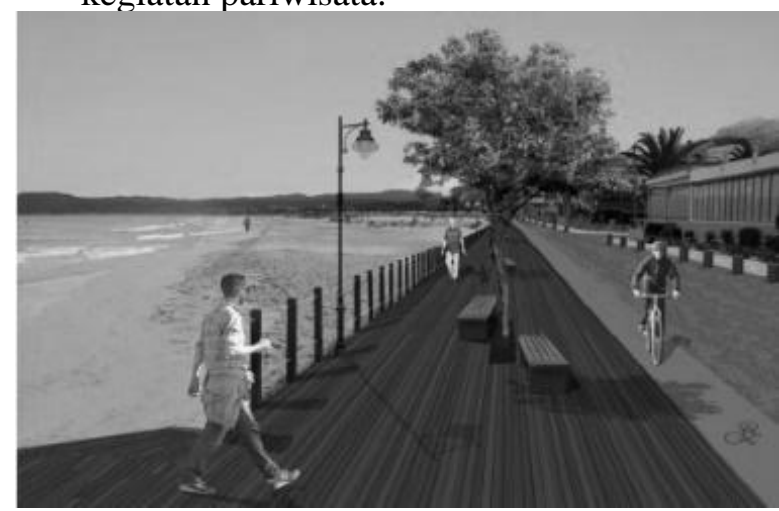

Gambar 5. Akses jalan yang mendukung kegiatan pariwisata Sumber: Kotsoni et al., 2017

4. Efektivitas dan Limitasi Pengembangan Hutan Pantai untuk Mereduksi Bencana Tsunami (Studi Kasus Pengembangan Hutan Pinus pada Pesisir Pantai di Jepang). Praktik baik ini diambil dari penelitian Tanaka (2012) yang berjudul Effectiveness and Limitations of Coastal Forest in Large Tsunami: Conditions of Japanese Pine Trees on Coastal Sand Dunes in Tsunami Caused by Great East Japan Earthquake. Coastal Forest berfungsi untuk meredam energi gelombang dan tsunami yang mencapai pantai yang termasuk mitigasi non struktural. Desain coastal forest terdiri atas 2 layer. Layer pertama berada pada pantai, sedangkan layer kedua berada pada 
tanggul alami yang lokasinya dekat dengan daratan [Gambar 6]. Fungsi tanggul alami dapat juga untuk menangkap debris saat tsunami. Antara layer pertama dan layer kedua terdapat jalur air (tanpa penanaman vegetasi).

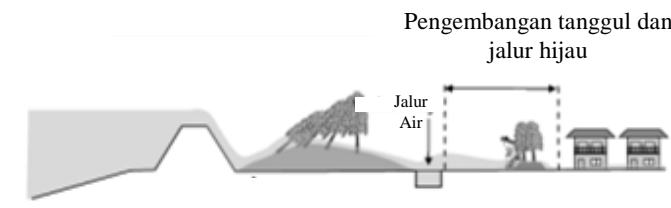

Gambar 6. Coastal Forest di Kawasan Pesisir Sumber: Tanaka, 2012

Konsep proteksi multi-layer diterapkan dengan pengembangan daerah penyangga dan penanaman vegetasi, pembangunan akses jalan, dan kawasan terbangun. Pada daerah penyangga dan penanaman vegetasi juga digunakan beberapa layer dengan tipologi bentang lahan yang berbeda. Gambar 7 menunjukkan Konsep MultiLayer pada Kawasan Pesisir Rawan Bencana Tsunami.

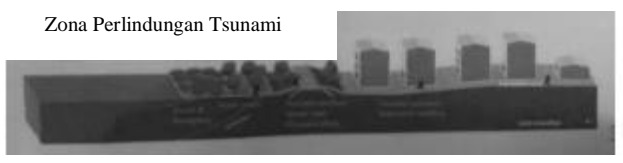

Gambar 7. Konsep multi-layer pada kawasan pesisir rawan bencana tsunami

Sumber: Tsimopoulou et al., 2012

5. Perencanaan dan Desain Sabuk Hijau pada Kawasan Pesisir Rawan Bencana Tsunami Elaborasi mitigasi struktural dan non struktural lebih efektif mengurangi dampak bencana tsunami. Pengembangan RTH maupun jalur hijau tidak akan efektif mengurangi dampak jika ketinggian tsunami di atas 5 (lima) meter. Pemanfaatan kawasan pesisir sebagai pemukiman, pariwisata, industri, dan lain sebagainya sangat sulit untuk mengembangkan RTH dalam lingkup yang luas, sehingga perlu upaya mitigasi struktural. Gambar 8 adalah elaborasi mitigasi struktural dan non struktural.

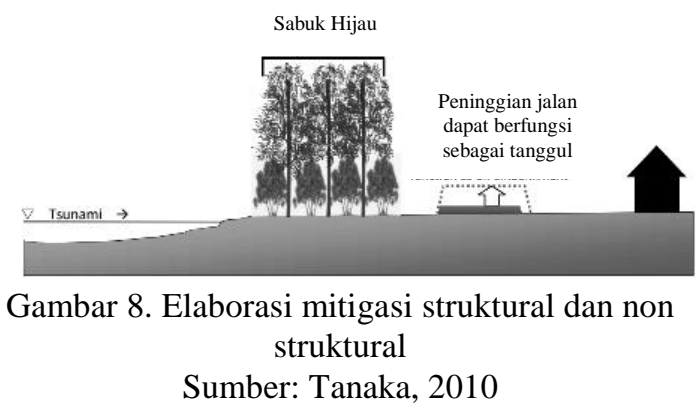

Penetapan Rencana Struktur Ruang dan

Rencana Pola Ruang berdasarkan

Kebutuhan Mitigasi Bencana/Pengurangan Risiko Bencana Tsunami

Penetapan rencana struktur ruang dan rencana pola ruang juga mempertimbangkan aspek mitigasi bencana/PRB. Pada bagian penetapan rencana struktur ruang dan rencana pola ruang mempertimbangkan kemampuan dan kesesuaian lahan dan pengaturan sistem pusat pelayanan, pembangunan infrastruktur, dan juga prasarana dan sarana yang dikembangkan pada KRB tsunami.

Pemanfaatan ruang yang dapat dikembangkan pada KRB tsunami juga dapat mempertimbangkan ancaman bencana. Penentuan rencana struktur ruang dan rencana pola ruang berdasarkan kebutuhan mitigasi bencana/pengurangan risiko bencana lebih menekankan pengembangan mitigasi struktural dan non struktural dan juga pengaturan terhadap pemanfaatan ruang sebagai antisipasi terhadap ancaman bencana tsunami.

Penetapan rencana struktur ruang perlu menambahkan infrastruktur mitigasi struktural dan non struktural dan juga sistem peringatan dini untuk mengurangi risiko bencana tsunami. Mitigasi struktural berfungsi untuk meredam dan mengurangi energi gelombang tsunami yang mencapai ke kawasan pantai hingga daratan.

Mitigasi struktural harus menyesuaikan mekanisme terjadinya tsunami, inventarisasi dan identifikasi kekuatan bangunan di KRB tsunami. Tanggul pantai, pemecah gelombang, pantai setimbang, tetrapod, pintu air, dan sistem 
peringatan dini sebagai contoh mitigasi struktural (Edyanto, 2015). Mitigasi non struktural sebagai sebagai upaya mitigasi dari struktur alami untuk melindungi kawasan dari bencana tsunami, seperti RTH dan hutan mangrove.

Tanggul pantai berupa tanah tinggi buatan yang dibangun dengan konstruksi beton yang memanjang sejajar dengan garis pantai. Pemecah gelombang sebagai mitigasi struktural lepas pantai yang dapat menghalangi terjangan gelombang tsunami dan badai ke pelabuhan. Tetrapod merupakan unit perlindungan terhadap tekanan gelombang pantai yang terbuat dari beton dengan empat kaki. Teknik menyusunan unit ini di garis pantai, sehingga akibat gelombang tsunami yang besar tidak terjadi pergeseran yang terlalu besar terhadap tetrapod tersebut. Pintu air pada kawasan pantai digunakan untuk melindungi lokasi tertentu terhadap gelombang tsunami. Pintu air ini akan bekerja secara otomatis dalam hitungan detik akan tertutup, setelah sensor sismik mendeteksi gempa. Sistem pertahanan struktural juga dibangun untuk membatasi ruang antara laut dan pemukiman dengan ketinggian tertentu. Pantai setimbang berfungsi untuk perlindungan dan pengelolaan garis pantai. Cara kerja pantai setimbang adalah garis pantai ini berorientasi secara pararel terhadap garis puncak gelombang datang, sehingga dapat meminimalkan transport sedimen disepanjang pantai dan dapat menghasilkan pola pantai seimbang. Sistem peringatan dini tsunami sebagai suatu sistem yang dirancang untuk mendeteksi bencana tsunami yang terdiri atas 2 (dua) jenis, yaitu sistem peringatan dini interasional dan sistem peringatan dini tsunami regional.

$$
\text { Mitigasi non struktural yang }
$$

dikembangkan di kawasan pantai adalah RTH berupa taman pantai dan mangrove sebagai kawasan pembatas yang peruntukkan sebagai kawasan konservasi dan pariwisata pantai terhadap zona terbangun di kawasan pantai. Kawasan ini juga dapat dibangun hutan pantai yang berfungsi sebagai penghadang terjangan tsunami dan dapat diperkuat dengan pembangunan bukit buatan hasil dari pengumpulan material debris tsunami sehingga terbentuk hutan pantai. Taman pantai dapat juga dimanfaatkan sebagai lapangan olah raga hingga fasilitas wisata pantai yang lain dengan tetap memperhatikan fungsi ekologinya, tetapi dapat diakses oleh masyarakat luas.

\section{Ketentuan Pemanfaatan Ruang KRB Tsunami}

Ketentuan pemanfaatan ruang akan menghasilkan arahan pengembangan mitigasi struktural dan non struktural beserta rencana pola ruangnya. Hasil analisis ini juga dapat menjadi masukan Perda Nomor 17/2012 tentang RTRW Kabupaten Karangasem dan Raperda Perubahan RTRW Kabupaten Karangasem.

Pengembangan mitigasi bencana pada sempadan pantai dan KRB tsunami dapat meminimalisir risiko bencana tsunami sekaligus sebagai aset pariwisata yang berkontribusi terhadap Pendapatan Asli Daerah dan dapat mendukung perkembangan perekonomian dari aspek pariwisata.

Penetapan sempadan pantai 100 meter dengan mempertimbangkan landaan tsunami di kawasan pesisir Kabupaten Karangasem. Dengan begitu penetapan Batas Sempadan Pantai (BSP) mempertimbangkan KRB tsunami, yaitu 100 meter yang dihitung dari titik pasang tertinggi ke arah daratan dengan luasan kurang lebih 826 hektar yang terletak di 4 (empat) kecamatan, yaitu Kecamatan Kubu, Kecamatan Abang, Kecamatan Manggis, dan Kecamatan Karangasem.

Penetapan sempadan pantai dengan mempertimbangkan landaan tsunami di kawasan pesisir Kabupaten Karangasem yang mencapai 100 meter. Sempadan pantai juga berfungsi sebagai zona penyangga (buffer zone) untuk mengurangi energi gelombang tsunami agar daya rusaknya menurun (Widiati, 2008). Dengan begitu ditetapkan Batas Sempadan Pantai (BSP) yang mempertimbangkan KRB tsunami, yaitu 100 meter yang dihitung dari titik pasang tertinggi ke arah daratan dengan luasan kurang lebih 826 hektar yang terletak di 4 (empat) kecamatan, yaitu Kecamatan Kubu, 
Kecamatan Abang, Kecamatan Manggis, dan Kecamatan Karangasem.

Penetapan sempadan pantai dapat ditindaklanjuti dengan rehabilitasi pantai untuk mengembalikan fungsi sempadan pantai. Rehabilitasi dapat dilakukan dengan penambahan pasir pantai (beach nourishment). Beach nourishment sebagai upaya merehabilitasi pantai untuk mengembalikan kawasan pantai dengan pengisian pasir (sand nourishment). Teknik ini tidak akan mengubah bentang lahan pantai karena bersifat sebagai struktur alami (Kementerian Pekerjaan Umum dan perumahan Rakyat, 2018). Beach nourishment perlu dilakukan secara kontinu untuk mengurangi dampak dari erosi atau berkurangnya kawasan pantai. Pasokan material pasir diambil dari lepas pantai atau lahan di sekitarnya. Pengisian material pasir sebagai suatu keharusan bagi pemulihan stabilitas pantai. Tindakan ini dapat bersifat terus menerus atau periodik, yang dihentikan setelah pasokan alami dapat terjadi lagi.

Keterlanjuran pemanfaatan ruang sempadan pantai perlu diimbangi dengan mitigasi bencana struktural dan non struktural. Pengembangan infrastruktur mitigasi struktural meliputi tanggul pantai dan pemecah gelombang. Infrastruktur mitigasi non struktural meliputi pengisian pasir pantai, sabuk hijau, dan kawasan mangrove. Kolaborasi infrastruktur mitigasi struktural dan non struktural dapat menjaga keseimbangan lingkungan. Sempadan sungai merupakan kawasan publik yang dapat diakses dan dimanfaatkan oleh wisatawan dan masyarakat, sehingga tidak diperbolehkan menutup akses pariwisata sebagai milik swasta ataupun privatisasi. Selain itu, untuk mendukung fungsi sempadan pantai maka wajib menyediakan akses publik, melakukan proteksi dan adaptasi bangunan terhadap bencana tsunami dan/atau konservasi pantai untuk mengembalikan sempadan pantai minimal 100 meter yang diperuntukan infrastruktur mitigasi struktural dan non struktural, dan penyediaan Tempat Evakuasi Sementara (TES) dan juga Tempat Evakuasi Akhir (TEA) sebagaimana [Gambar 9].

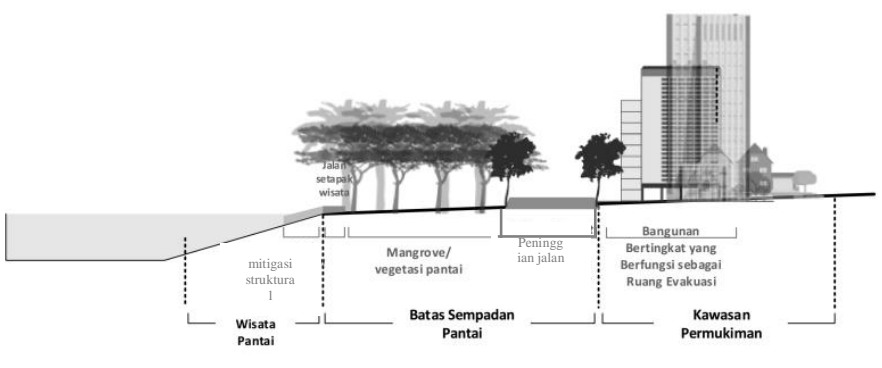

Gambar 9. Pemanfaatan ruang kawasan pesisir Kabupaten Karangasem

Sumber: Draft pedoman pemanfaatan ruang Kawasan Sempadan Pantai, 2019

Penyediaan sistem evakuasi dapat dikembangkan bersama oleh pemerintah dan pihak swasta karena melibatkan kedua pihak tersebut. Rambu dan papan informasi yang terdapat di KRB tsunami, terutama di hotel dan restoran memberikan informasi level KRB pada lokasi tersebut (ASEAN, 2016). Bangunan hotel di KRB tsunami dapat berfungsi sebagai TES dengan begitu persyaratan dari bangunan hotel adalah minimal 2 lantai, sedangkan TEA adalah lokasi yang aman dari bencana tsunami. Pengembangan sistem evakuasi perlu mempertimbangkan sistem peringatan dini baik pada aset pariwisata dan permukiman di sepanjang pesisir Kabupaten Karangasem.

Tabel 1. Rencana sistem evakuasi bencana tsunami

\begin{tabular}{|c|c|}
\hline No. & Jalur Evakuasi \\
\hline 1 & $\begin{array}{l}\text { Angantelu ke Jalan Yeh Malet ke Pertigaan } \\
\text { Pakel }\end{array}$ \\
\hline 2 & $\begin{array}{l}\text { Padangbai-Silayukti ke Angantelu- } \\
\text { Padangbai }\end{array}$ \\
\hline 3 & $\begin{array}{l}\text { Jalan Pantai-Ulakan ke Batas Kota } \\
\text { Amlapura-Angantelu }\end{array}$ \\
\hline 4 & Jalan Tanah Ampo ke Jalan Pantai \\
\hline 5 & $\begin{array}{l}\text { Jalan Batas Kota Amlapura-Angantelu ke } \\
\text { Jalan Sengkidu Ke Jalan Ngis }\end{array}$ \\
\hline 6 & Jalan Raya Sengkidu \\
\hline 7 & Jalan Pertigaan Samuh ke Jalan Samuh \\
\hline 8 & $\begin{array}{l}\text { Jalan Bugbug ke Batas Kota Amlapura- } \\
\text { Angantelu }\end{array}$ \\
\hline 9 & $\begin{array}{l}\text { Jalan Labuhan ke Jalan Labuhan Amuk ke } \\
\text { Jalan Padang Bai ke Angantelu-Padangbai }\end{array}$ \\
\hline 10 & Batas Kota Amlapura- Angantelu \\
\hline
\end{tabular}

Sumber: Hasil pengolahan data tim penyusunan masterplan Kawasan Rawan Bencana (KRB) Gunung Agung di Kabupaten Karangasem, 2019 
Jalur evakuasi tidak hanya terdapat di kawasan pariwisata, tetapi juga pada kawasan permukiman. Jaringan jalan di sekitar pantai sebagai akses publik, sehingga pada saat bencana akses terbuka untuk wisatawan dan masyarakat. Jalur evakuasi harus terkoneksi dengan jaringan arteri dan moda transportasi yang digunakan untuk transportasi menuju
TEA. Pemasangan sistem peringatan dini di beberapa titik kawasan pesisir Kabupaten Karangasem. Pengembangan sistem peringatan dini berfungsi untuk memberikan tanda dan peringatan jika terjadi gempa bumi, maka gempa bumi tersebut memicu terjadinya tsunami.

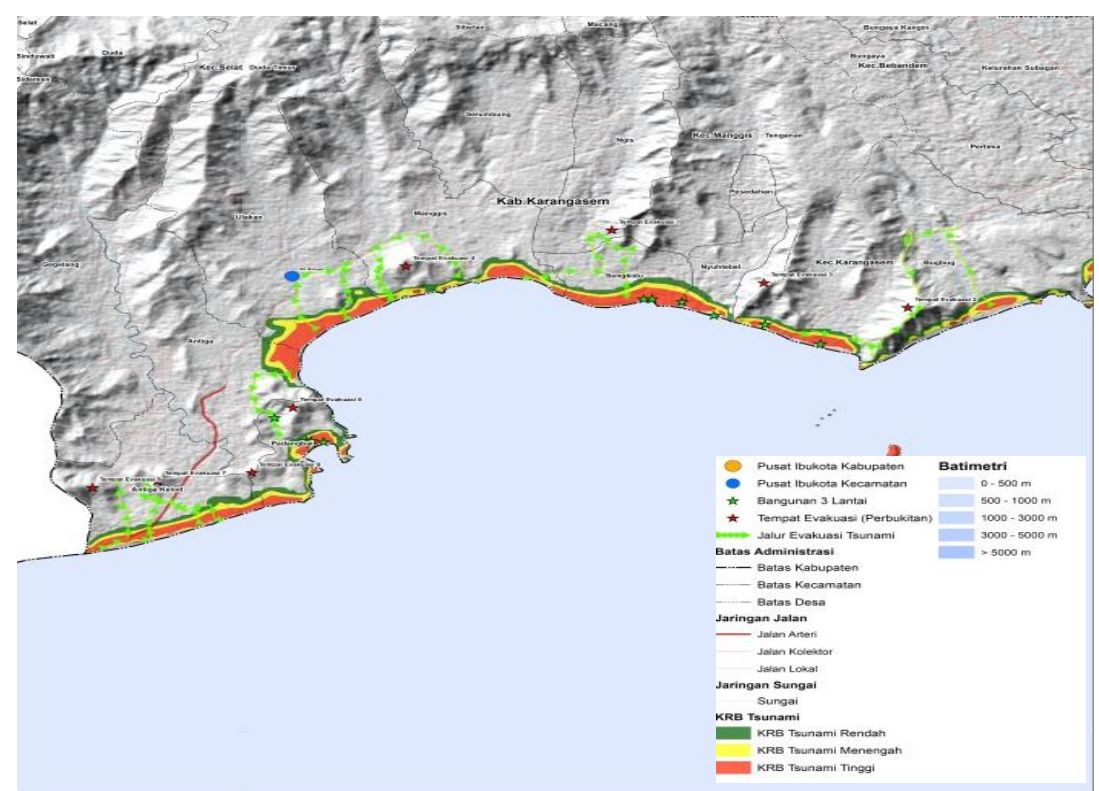

Gambar 6. Jalur evakuasi bencana tsunami Kabupaten Karangasem

Sumber: Hasil pengolahan data tim penyusunan masterplan Kawasan Rawan Bencana (KRB) Gunung Agung di Kabupaten Karangasem, 2019

Sistem peringatan dini dilengkapi oleh peralatan berupa seismometer, GPS, Buoy, tide Gauge, dan juga sistem komunikasi yang mengintegrasikan semua peralatan menjadi suatu sistem pemantauan yang sesuai dengan waktu sebenarnya dan kontinu. Sistem peringatan dini tsunami terdiri atas bagian upstream dan downstream. Data peralatan observasi, misalnya seismometer akan mengalir dalam bagian sistem informasi bencana tsunami yang dioperasikan oleh Badan Meteorologi, Klimatologi, dan Geofisika (BMKG). Data tersebut kemudian digunakan sebagai dasar untuk menentukan peringatan kejadian tsunami. Ketika BMKG memutuskan untuk mengeluarkan peringatan tsunami, maka proses downstream dimulai dengan menyebarkan informasi tersebut ke institusi di daerah dan media elektronik. Institusi daerah harus segera merespon dengan meneruskan informasi peringatan dan arahan penyelamatan diri kepada masyarakat.

Keterbatasan waktu dan kondisi ketidakpastian terkait dengan bahaya tsunami lokal dan peringatan dini merupakan satu tantangan besar bagi kawasan pesisir di Kabupaten Karangasem. Pengembangan sistem peringatan dini bencana merupakan bentuk kesiapsiagaan. Pada saat alarm atau sirine berbunyi dari sistem peringatan dini harus memberikan waktu kepada masyarakat dan wisatawan untuk mencapai TES sebelum terjangan tsunami mencapai daratan.

Pada KRB tsunami terdapat pemanfaatan ruang sebagai kawasan pariwisata dan kawasan permukiman yang juga memerlukan mitigasi bencana. Pada kawasan tersebut perlu dikembangan infrastruktur mitigasi struktural dan non struktural dan juga sistem evakuasi. Kegiatan transportasi diperbolehkan asalkan 
mendukung proses evakuasi. Dengan begitu diperlukan rekayasa lalu lintas untuk mengatur pergerakan yang tidak menghambat proses evakuasi pada saat terjadi bencana tsunami.

Pengembangan sarana dan prasarana penunjang pariwisata dengan konstruksi bangunan tahan gempa dan dapat berfungsi ganda sebagai tempat evakuasi vertikal bencana tsunami. Akomodasi dan penunjang pariwisata dengan desain struktur bertingkat maksimal 15 meter yang sekaligus difungsikan sebagai TES tsunami, bila berjarak lebih dari 100 meter dari perbukitan terdekat.

Pada kawasan permukiman yang berada pada KRB tsunami, dapat beradaptasi dengan desain huniannya menggunakan konstruksi bangunan tahan gempa dan dapat berfungsi ganda sebagai tempat evakuasi vertikal bencana tsunami (Berkes et al., 2003).

Pemanfaatan fasilitas umum dan/atau sarana prasarana di kawasan permukiman dengan struktur bangunan bertingkat maksimal 15 meter yang sekaligus difungsikan sebagai TES tsunami, bila berjarak lebih dari 100 meter dari perbukitan terdekat. Tabel 1 menunjukkan arahan rekomendasi pengembangan mitigasi struktural dan non struktural. Tabel 2 menunjukkan arahan rekomendasi pengembangan mitigasi struktural dan non struktural.
Tabel 2. Arahan Rekomendasi Pengembangan Mitigasi Struktural dan Non Struktural

\begin{tabular}{ll}
\hline No & $\begin{array}{l}\text { Program Mitigasi Bencana/Pengurangan } \\
\text { Risiko Bencana Tsunami }\end{array}$ \\
\hline A & Infrastruktur Mitigasi Struktural \\
1 & Pengembangan sistem evakuasi \\
2 & Pengembangan sistem peringatan dini \\
3 & $\begin{array}{l}\text { Pengembangan infrastruktur penahan } \\
\text { gelombang }\end{array}$ \\
4 & Pengembangan akomodasi pariwisata yang \\
& berbasis mitigasi bencana/Pengurangan Risiko \\
& Bencana \\
B & Infrastruktur Mitigasi Non Struktural \\
1 & Rehabilitasi pantai \\
2 & Pengembangan sabuk hijau di kawasan pantai \\
3 & Pengembangan RTH \\
\hline
\end{tabular}

Pengaturan pemanfaatan ruang pada KRB tsunami terbatas dan bersyarat. Pengaturan ini juga perlu memperhatikan perspektif ruang relasional (Yusup, 2014). Dalam artian pemanfaatan ruang kawasan budidaya perlu mempertimbangkan kerawanan bencana tsunami. Hal ini bertujuan untuk mengendalikan pemanfaatan ruang pada KRB tsunami. Kegiatan budidaya non terbangun diperbolehkan pada sempadan pantai dan KRB tsunami, sedangkan kegiatan budidaya terbangun diperbolehkan hanya pada KRB I dan KRB II. Pengembangan kawasan pelabuhan diperbolehkan pada sempadan pantai. Tabel 3 menunjukkan arahan rekomendasi pemanfaatan ruang pada sempadan pantai dan KRB tsunami.

Tabel 3. Arahan Rekomendasi Pemanfaatan Ruang pada Sempadan Pantai dan KRB Tsunami

Peruntukan atau Fungsi Ruang
KAWASAN HUTAN PRODUKS
Hutan produksi terbatas
Hutan produksi tetap
Hutan produksi yang dapat diko
KAWASAN PERTANIAN
Pertanian tanaman pangan
Pertanian hortikultura
Perkebunan
Peternakan
Pertanian Pangan Berkelanjutan
Sempadan Pantai KRB I KRB II KRB III

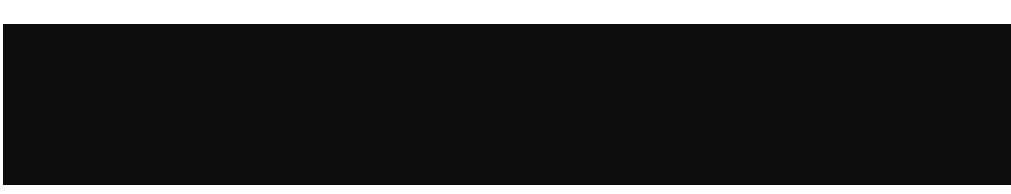


Journal of Regional and Rural Development Planning (Jurnal Perencanaan Pembangunan Wilayah dan Perdesaan)

Februari 2021, 5 (1): 1-14

Tabel 3. Lanjutan

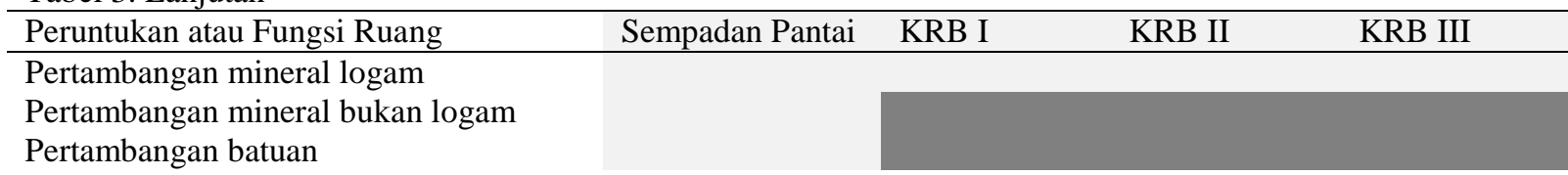

KAWASAN PERTAMBANGAN BATUBARA

Pertambangan batubara

KAWASAN PERTAMBANGAN MINYAK DAN GAS BUMI

Pertambangan minyak dan gas bumi

Pertambangan minyak dan gas bumi

(laut)

KAWASAN PANAS BUMI

Panas bumi

KAWASAN PEMBANGKIT TENAGA LISTRIK

Pembangkit tenaga listrik

KAWASAN PERIKANAN

Perikanan tangkap

Perikanan budidaya

KAWASAN PERUNTUKAN INDUSTRI

Industri

Industri kecil dan menengah

KAWASAN PARIWISATA

Pariwisata

KAWASAN PERMUKIMAN

Perumahan

Perdagangan dan Jasa

Perkantoran

Ruang Terbuka Hijau

Tempat Evakuasi Bencana

Sektor Informal

Peribadatan

Pendidikan

Kesehatan

Olahraga

Transportasi

Sumber Daya Air

Kawasan Keselamatan

Operasi Penerbangan

(KKOP)

JARINGAN PRASARANA

Terminal

Stasiun

Pelabuhan

Bandar Udara

Persampahan

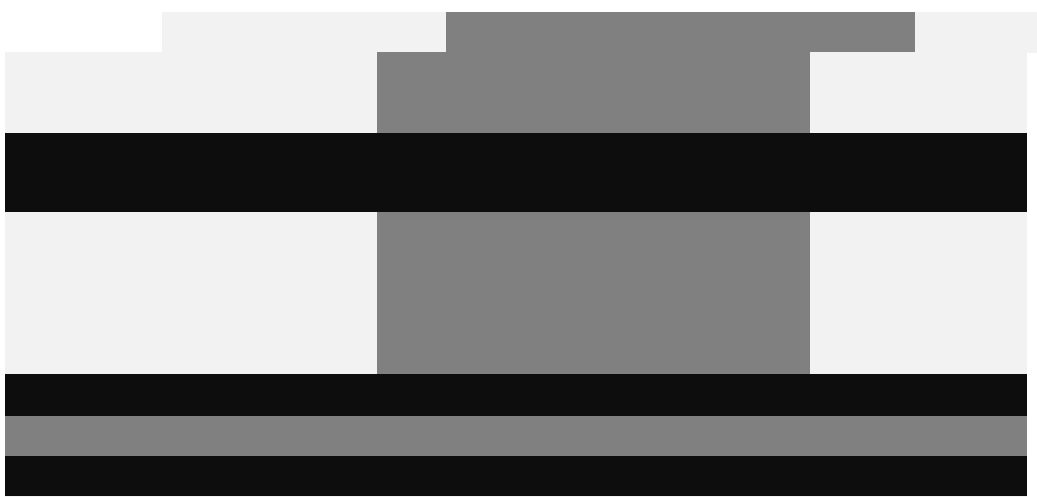

Keterangan:

Kegiatan yang Diperbolehkan

Kegiatan yang Diperbolehkan dengan Syarat

Kegiatan yang Tidak Diperbolehkan 


\section{KESIMPULAN DAN REKOMENDASI}

Sempadan pantai dan KRB III tsunami ditetapkan sebagai kawasan lindung. Keterlanjuran pemanfaatan ruang sempadan pantai perlu diimbangi dengan mitigasi bencana struktural dan non struktural. Pengembangan infrastruktur mitigasi struktural meliputi tanggul pantai dan pemecah gelombang di sepanjang kawasan pesisir Kabupaten Karangasem.

Akomodasi dan penunjang pariwisata dengan desain struktur bertingkat maksimal 15 (lima belas) meter atau minimal 3 (tiga) lantai dengan mempertimbangkan sejarah tsunami dan landaan tsunami yang sekaligus difungsikan sebagai Tempat Evakuasi Sementara (TES) tsunami, bila berjarak lebih dari 100 meter dari perbukitan terdekat.

Pada kawasan permukiman yang berada pada KRB tsunami, desain huniannya menggunakan konstruksi bangunan tahan gempa dan dapat berfungsi ganda sebagai tempat evakuasi vertikal bencana tsunami.

\section{UCAPAN TERIMA KASIH}

Penulis ucapkan terimakasih kepada Kementerian Agraria dan Tata Ruang/BPN yang telah memberikan kesempatan kepada penulis untuk berkontribusi pada kegiatan Penyusunan Masterplan Kawasan Rawan Bencana (KRB) Gunung Agung di Kabupaten Karangasem. Hasil dari kegiatan tersebut menjadi acuan dalam kajian "Konsep penataan ruang Kawasan Rawan Bencana (KRB) Gunungapi Agung di Kabupaten Karangasem, Pulau Bali”.

\section{DAFTAR PUSTAKA}

Areti, K., Dimelli, D. \& Ragia, L. (2017). Land Use Planning for Sustainable Development of Coastal Regions. Proceedings of the 3rd International Conference on Geographical Information Systems Theory, Applications and Management (GISTAM 2017), ISBN: 978-989-758-252-3, 290294.

Association of Southeast Asian Nations (ASEAN). (2016). ASEAN Community Based Tourism Standard. ASEAN.

Badan Geologi. (2013). Pemetaan Kawasan Rawan Bencana Tsunami.

Berkes, F., Colding, J. \& Folke, C. (2003). Navigating Social-Ecological Systems. Cambridge University Press.

Blaikie, P., Cannon, T., Davis, I. \& Wisner, B. At Risk: Natural Hazards, People's Vulnerability and Disasters. Routledge.

BMKG. (2018). Catatan Sejarah Gempa di Bali. BMKG.

Cross, J. A. (2001). Megacities and Small Towns: Different Perspectives on Hazard Vulnerability. Environmental Hazards, 3 (2), 63-80.

Edyanto, H. (2015). Sistem Pertahanan Kombinasi untuk Melindungi Kota Pantai dari Bahaya Tsunami. Jurnal Sains dan Teknologi Indonesia, 17,2.

Kementerian Agraria dan Tata Ruang/Badan pertanahan Nasional. (2019). Draft Pedoman Pemanfaatan Ruang Kawasan Sempadan Pantai.

Kementerian Pekerjaan Umum dan Perumahan Rakyat. (2018). Coastal Protection and Beach Nourishment in Indonesia. Dipresentasikan dalam International Symposium Beach Erosion Management in East Asia pada 1 November 2018. 
Peraturan Menteri Agraria dan Tata Ruang/Kepala Badan Pertanahan Nasional No 1 Tahun 2018 tentang Pedoman Penyusunan Rencana Tata Ruang Wilayah Provinsi, Kabupaten, dan Kota.

Peraturan Daerah Kabupaten Karangasem Nomor 17 Tahun 2012 Tentang Rencana Tata Ruang Wilayah Kabupaten Karangasem Tahun 2012-2032.

Soemabrata, J., Zubair, A., Sondang, I., \& Suyanti, E. (2018). Risk mapping studies of Hydro-Meteorological Hazard in Depok Middle City. International Journal of GEOMATE, 14 (44), 128-133.

Sutanta, H. (2012). Spatial planning support system for an integrated approach to disaster risk reduction. $\mathrm{PhD}$ thesis, Centre for Spatial Data Infrastructures \& Land Administration, Department of Infrastructure Engineering, The University of Melbourne.

Tanaka, N. (2012). Effectiveness AND Limitations of Coastal Forest in Large Tsunami: Conditions of Japanese Pine Trees On Coastal Sand Dunes in Tsunami Caused by Great East Japan Earthquake. Journal of Japan Society of Civil Engineers. 68, 7-15.

Tsimopoulou, V., Jonkman, S. N., Kolen, B., Maaskant, B., Mori, N. \& Yasuda, T. (2013). A Multi Layered Safety Perspective on The Tsunami Disaster in Tohoku Japan. Comprehensive Flood Risk Management. Taylor \& Francis Group. London.

Undang-Undang Nomor 24 Tahun 2007 tentang Penanggulangan Bencana.

Undang-Undang Nomor 26 Tahun 2007 tentang Penataan Ruang.

Widiati, A. 2008. Aplikasi Manajemen Risiko Bencana Alam dalam Penataan Ruang Kabupaten Nabire. Jurnal Sains dan Teknologi Indonesia, 10 (1), 7-15.
Yusup, Y. 2014. Hidup Bersama Risiko Bencana: Konstruksi Ruang dalam Perspektif Ruang Reasional. Jurnal Perencanaan Wilayah dan Kota, 25 (1), 59-77. 